Пішковці А.-M.M., Палко А.I., Рогач I.M.

\title{
Наукове обгрунтування нових підходів до первинної, вторинної та третинної профілактики стоматологічних захворювань населення Закарпатської області
}

\author{
ДВНЗ «Ужгородський національний університет», м.Ужгород, Україна \\ annamariaremez@gmail.com,palko.alice@gmail.com
}

Пишковци А.-М.М., Палко А.И., Рогач И.М.

Научное обоснование новых подходов к первичной, вторичной и третичной профилактике стоматологических заболеваний населения Закарпатской области

ГВУЗ «Ужгородский национальный университет», г. Ужгород, Украина
Pishkovtsi A.-M.M., Palko A.I., Rogach I.M. Scientific substantiation of new approaches to the primary, secondary and tritinal prevention of dental diseases of the population of the Transcarpathian region

Uzhhorod National University, Uzhhorod, Ukraine

\section{Вступ}

Організація i проведення профілактики стоматологічних захворювань $є$ одним 3 найважливіших завдань сьогодення i має здійснюватися на основі використання результатів наукових досліджень.

Проблеми профілактики стоматологічних захворювань $\epsilon$ не тільки стоматологічною, а і державною проблемою. Профілактика стоматологічних захворювань $\epsilon$ економічно виправданим, перспективним та ефективним напрямом розвитку стоматології, особливо дитячого віку $[1,2]$.

В багатьох європейських країнах доведена висока медична ефективність комунальних програм первинної профілактики, які передбачають: фторування води, гігієну ротової порожнини, раціональне обмеження частоти прийому вуглеводної їжі [3-5], однак виникає необхідність розробки нових інноваційних технологій та корекцію вже діючих профілактичних заходів, які б грунтувалися на сучасному рівні інформації про патогенез та зв'язку із чинниками ризику для конкретних регіонів $[6,7]$.

Мета - аналіз досвіду профілактики основних стоматологічних захворювань країн Свропи з схожими біогеохімічними показниками, як Закарпаття і розробка науково-обгрунтованих профілактичних заходів.

\section{Матеріали та методи}

Аналітичний аналіз основних напрямів стоматологічної первинної, вторинної і третинної профілактики та матеріалів статистичного центру МO3 України за 2017 і 2018 роки 3 використанням статистичного, соціологічного та клінічного методу проаналізовані статистичні дані щодо стоматологічного здоров'я дітей Закарпаття за 2017-2018 рр.

\section{Результати дослідження та їх обговорення}

Профілактика стоматологічних захворювань i карієсу зубів зокрема, як одного із найпоширеніших захворювань у дитячого і дорослого населення в Україні, $\epsilon$ важливим соціально-орієнтованим видом профілактичної роботи. Сучасні підходи до створення профілактичних програм в стоматології передбачають визначення факторів ризику формування i прогресування стоматологічних захворювань та зменшення їх негативного впливу на стан стоматологічного здоров'я.

Зниження стоматологічної захворюваності населення сусідніх Східно Європейських країн (Словаччина, Угорщина) мотивує провести аналітичний аналіз основних напрямів стоматологічної ендогенної та екзогенної профілактики.

З 1997 року на території, сусідньої з Закарпаттям, Словаччини працює програма «Здорова посмішка Словаччини» i в результаті виявлено зниження рівня поширеності основних стоматологічних захворювань у дітей різного віку з урахуванням особливостей психології дітей. За час дії програми поширеності та інтенсивність карієсу постійних зубів у дітей знизилась з 85\% до $15 \%$ і тримається на цьому рівні довгий період $[8,9]$. Основна перевага цієї програми базується на мотивації молоді різної вікової групи, позбавлення відчуття страху перед стоматологічними маніпуляціями та взагалі страху перед стоматологом i стоматологічним кабінетом. Стоматологічне гігієнічне навчання починається в дошкільних закладах і продовжується у шкільних закладах.

Показники стоматологічного здоров'я населення Угорщини гірші за показниками країн Євросоюзу. В залежності від регіону можуть спостерігатися стоматологічні хвороби у $80-100 \%$ населення, однак і тут профілактику стоматологічних захворювань вважають 
основною стратегією XX1 століття поряд 3 іншими захворюваннями $[10,11]$.

В Україні, за результатами досліджень проведених впродовж останніх років, виявлено, що поширеність та інтенсивність карієсу серед дітей різної вікової групи України залишається на високому рівні і становить 65,8$97,7 \%$ [12].

У практичній стоматології профілактику здійснюють на різних рівнях: перед первинну (для вагітних), первинну, вторинну і третинну. Профілактичні заходи та програми розроблені з врахуванням факторів ризику (вік, соціальний стан, екологічна ситуація), досягнень стоматологічної інвазійної технології, стоматологічної культури населення. Проводиться анкетування населення i на основі ii результатів визначається відповідна програма профілактики. Також велике значення надається ранній діагностиці через стоматологічні профілактичні огляди, гігієнічному навчанню населення, студентів та інтернів стоматологічних вузів. Широко використовують для цього засоби масової інформації, цифрова технологія, спеціальні курси для підготовки спеціалістів $[13,14]$.

Враховуючи, що у профілактиці карієсу та патології прикусу велике значення має біологічна цінність добового харчового раціону та характер їжі було проведене соціологічне дослідження серед обстежених дітей до 17 p. м. Ужгород з метою вивчення їх способу харчування.

На основі результатів опитування обстежених дітей виявлено, що у добовому харчовому раціоні дітей, не залежно від віку і статі, у яких виявлено карієс зубів, мається досить одноманітний набір харчових продуктів. Встановлено, що діти мало споживають молока та молочно-кислих продуктів, що може бути причиною зниження кількісті кальцію та фосфору в організмі. Виявлено, що щодня молоко і молочно кислі продукти входять до складу харчового раціону дітей в віці 9 років життя у 45,0\%, $10-12$ років життя - 26,0\%, 15 років життя - 35,0\% [15].

В Україні вперше 21 травня 2002 р. Указом Президента затверджена «Програма профілактики та лікування стоматологічних захворювань на $2002-$ 2007 роки» $[16,17]$.

На сьогоднішній день в нашій країні відсутня загальнодержавна програма профілактики стоматологічних захворювань, а розробляються регіональні та місцеві програми 3 врахуванням особливості регіону і вони є недостатньо якісними.

Закарпатська область $є$ біогеохімічною територією iз низьким вмістом йоду та фтору, наявними проблемами розвитку i функціонування стоматологічної служби, що несприятливо відображається на поширенні стоматологічних захворювань у населення [18].

При цьому все більшої актуальності набуває індивідуальна профілактика стоматологічних захворювань. Доцільним $є$ впровадження безперервно діючих програм у формі індивідуального систематичного стоматологічного контролю та профілактичних стоматологічних оглядів. Основне місце в стоматологічній практиці для збереження стоматологічного здоров'я займає профілактична робота: проведення обов'язкових профілактичних оглядів, планова санація населення, запровадження системи гігієнічного навчання та виховання населення 3 питань стоматологічного здоров'я.

$$
3 \text { кожним роком кількість охоплених }
$$
профілактичними оглядами дітей в Закарпатській області зменшується, наприклад у 2018 році на 7,1\% менше, ніж у 2009 році [5].

Результати аналізу показників діяльності стоматологічних закладів охорони здоров'я системи МО3 України що представлені в таблиці, свідчать про зменшення кількості відвідувань до лікарів - стоматологів у 2018 році порівняно з 2017 роком як всього населення Закарпатської області (відповідно 1017530 та 894006 звернень), так і дітей віком до 17 років життя включно.

Виявлено, що в Закарпатській області у 2017 році санацію потребувало 310697 осіб, а у 2018 році 286687 осіб. Серед дорослого населення віком 18 років і старше, оглянутого у порядку планової санації, потребували санації у 2018 році 73,2\% з числа оглянутих жителів області.

Аналізи результатів частки первинних відвідувань до лікарів-стоматологів серед усіх відвідувань до лікарів стоматологічного профілю показують, що значне коливання цього показника для дорослих та для дітей віком до 17 років життя не характерно.

Питома вага санованих при плановій санації від кількості, що її потребували у 2018 році в Закарпатській області серед дорослого населення віком 18 років і старше становила $86,0 \%$.

Серед дітей віком до 17 років життя включно відсоток санованих від кількості, що іiї потребували в області у 2018 році становив 85,4.

Встановлено, що питома вага пролікованих зубів 3 приводу карієсу до усіх стоматологічних відвідувань серед дорослого населення віком 18 років і старше у 2018 році становила $121,9 \%$. У дітей віком до 17 років включно в Закарпатській області у 2018 році питома вага пролікованих зубів з приводу карієсу становила 90,3\%, що більше, ніж у 2017 році $(83,2 \%)$.

Поряд із первинною профілактикою актуальним $\epsilon$ вторинна i третинна профілактика стоматологічних захворювань (глибоке фторування) [19], також поєднання засобів екзогенної та ендогенної профілактики для підвищення резистентність тканин ротової порожнини та організму в цілому.

Перспективи подальших досліджень пов'язані 3 вивченням ефективності профілактичних заходів серед населення гірської географічної зони Закарпатської області. 
Таблиця. Показники діяльності стоматологічної служби Закарпатської області за 2017, 2018 роки (закладів охорони здоров'я системи МОЗ України)

\begin{tabular}{|c|c|c|c|c|c|c|}
\hline \multirow[b]{3}{*}{ Показник } & \multicolumn{3}{|c|}{2017} & \multicolumn{3}{|c|}{2018} \\
\hline & \multirow[b]{2}{*}{$\begin{array}{c}\text { Все } \\
\text { населення }\end{array}$} & \multicolumn{2}{|c|}{ з них: } & \multirow[b]{2}{*}{$\begin{array}{c}\text { Все } \\
\text { населення }\end{array}$} & \multicolumn{2}{|c|}{3 них: } \\
\hline & & $\begin{array}{c}\text { дорослого } \\
\text { населення } \\
\text { віком } \\
18 \text { років } \\
\text { і старші }\end{array}$ & $\begin{array}{c}\text { дітей віком } \\
\text { до } 17 \text { років } \\
\text { включно }\end{array}$ & & $\begin{array}{c}\text { дорослого } \\
\text { населення } \\
\text { віком } \\
18 \text { років } \\
\text { і старші }\end{array}$ & $\begin{array}{c}\text { дітей віком } \\
\text { до } 17 \text { років } \\
\text { включно }\end{array}$ \\
\hline $\begin{array}{l}\text { Кількість відвідувань } \\
\text { до лікарів-стоматолог } \\
\text { та зубних лікарів - } \\
\text { усього (абс. числа) }\end{array}$ & 1017530 & 654311 & 363219 & 894006 & 569322 & 324684 \\
\hline $\begin{array}{l}\text { Питома вага первинн } \\
\text { відвідувань до лікарів } \\
\text { стоматологів серед ус } \\
\text { відвідувань до лікарів } \\
\text { стоматологічного } \\
\text { профілю (у \%) }\end{array}$ & 56,1 & 56,0 & 56,3 & 58,8 & 59,7 & 57,1 \\
\hline $\begin{array}{l}\text { Потребують санації } \\
\text { (абс. числа) }\end{array}$ & 310697 & 151494 & 159203 & 286687 & 146498 & 3969 \\
\hline $\begin{array}{l}\text { Серед оглянутих } \\
\text { у порядку планової } \\
\text { санації потребують } \\
\text { санації до кількості } \\
\text { оглянутих (у \%) }\end{array}$ & 74,1 & 74,7 & 73,6 & 73,7 & 73,2 & 74,2 \\
\hline $\begin{array}{l}\text { Питома вага } \\
\text { пролікованих зубів } 3 \\
\text { приводу карієсу до ус } \\
\text { стоматологічних } \\
\text { відвідувань (у \%) }\end{array}$ & 102,7 & 113,5 & 83,2 & 121,9 & 121,9 & 90,3 \\
\hline
\end{tabular}

\section{Висновки}

1. Профілактика стоматологічних захворювань $\epsilon$ ефективним та економічно виправданим методом розвитку стоматологічної медицини, що доведено програмами країн Європи, які можуть бути перспективним для застосування в Україні.

2. Високий рівень поширеності та інтенсивності карієсу в Україні, що складає 65,8-97,7\%, в порівнянні 3 країнами Євросоюзу підтверджують, що показовим є державна програма Словаччини, де за останні 20 років цей показник тримається на одному рівні, тому Україні необхідна своя державна програма та якісні комплексні регіональні програми первинної, вторинної та третинної профілактики стоматологічних захворювань.

3. Найбільш ефективним способом профілактики стоматологічних захворювань i підвищення стоматологічного здоров'я $\epsilon$ гігієнічне навчання всіх верств населення, особливо дитячого, застосування комунальної програми профілактики, проведення профілактичних стоматологічних оглядів та санація i диспансеризація.

\section{References}

1. Proekt Koncepciji derzhavnoji mizhghaluzevoji proghramy «Stomatologhichne zdorov’ja na 2008-2017 roky». Rezhym dostupu : ghttp://www.rada.gov.ua/cgi-bin/laws/main.cgi.

2. Savychuk N.O., Klitynsjka O.V. Analiz proghram profilaktyky osnovnykh stomatologhichnykh zakhvorjuvanj u rozvynenykh krajinakh. Sovremennaja stomatologhija. 2014; $4: 64-6$.

3. Avraamova O.Gh. Ftorydy v pytj'evoj vode y profylaktyka karyesa. Rossyjskyj stomatologhycheskyj zhurnal. 2012; $5: 36-8$.

4. Ghalasheva A.K, Ghromova S.N., Klepykova N.Y. Yzuchenye vlyjanyja urovnja soderzhanyja ftorydov v pytj'evoj vodoprovodnoj vode na razvytye karyoznogho processa u 12-letnykh detej goroda Kyrova y Kyrovskoj oblasty. Stomatologhyja detskogho vozrasta y profylaktyka stomatologhycheskykh zabolevanyj. Materyaly II Rossyjskogho Reghyonaljnogho konghressa Mezhdunarodnoj assocyacyy stomatologhyy IAPD, 29 sentjabrja - 1 oktjabrja. Moskva. $2014 ; 303$ - 6. 
5. Y. Jiang, L.A. Foster [et al.] Is New Zealand water fluoridation justified?. N Z Med J. 2014; $127: 80-6$.

6. Kosenko K.N., Denjgha O.V. Strateghyja profylaktyky osnovnыkh stomatologhycheskykh zabolevanyj s uchetom ykh эpydemyologhyy y byogheokhymycheskykh 180 osobennostej Ukrayny. Visnyk stomatologhiji. $2009 ; 4: 24$.

7. Savychuk N.O., Trubka I.O. Preventyvna terapija i profilaktyka karijesu zubiv - suchasni tendenciji. Ukrajinsjkyj stomatologhichnyj aljmanakh. 2013; 5 : 126-130.

8. Koval’ová E., Eliašová A., Hudáková L., Fedurcová I. Preventívny projekt skupinovej prevencie «zdravý úsmev». Materials of ii international conference of dentistry of students and young scientists february 8-9, 2013; «Current issues in the treatment and prevention of dental diseases». $194-7$

9. Skuljsjka S.V., Nadutyj K.O., Malanchuk V.O., Mazur I.P., Vakhnenko O.M. «Stomatologhichne zdorov’ja rozkish? Do pytannja optymizaciji systemy stomatologhichnoji dopomoghy v Ukrajini». Medychna ghazeta «Zdorov’ja Ukrajiny 21 storichchja». 2018; 22 (443).

10. Petersen P.E., Kwan S. Equity. Social determinant and public health programmes - the case of oral health. Community Dentistry and Oral Epidemmiology. 2011; $39: 481-7$.

11. Méhes Dental Clinic. - Rezhym dostupu : mehesfogorvos.hu/a-fogszuvasodasrol.

12. Bauman S.S., Turchina K.V., Mosijenko A.S., Padalka A.I., Sheshukova O.V. Porivnjaljna ocinka urazhenosti karijesom zubiv ditej m. Poltavy. Visnyk problem biologhiji ta medycyny. 2017; 2 (3) : 165 - 7.

13. Dr. Gera István. Paradontális prevenciós stratégia a XX1 században. Magyar Fogorvos. $2014 ; 5$ : $216-220$.

14. Dr. Pinke Ildikó. Preventiv szemlélet a praxisban. Magyar Fogorvos. 2014; 5 : 228-231.

15. Pishkovtsi A-M. M., Rohach I. M., Keretsman A. O., Palko A. I., Tsyhyka O. I. State of dental health of children in Uzhhorod and the way of their nutrition. Wydawnictwo Aluna. Wiadomości Lekarskie 2020; 73 (1) : 76.

16. Pro proghramu profilaktyky ta likuvannja stomatologhichnykh zakhvorjuvanj na 2002-2007 roky : Ukaz Prezydenta Ukrajiny vid 21 trav. 2002 r. \# 475/2002. - Rezhym dostupu : http: www.rada.gov.ua.

17. Shevcov V. Gh. Proghramno-ciljove upravlinnja jak osnova rozvytku komunaljnogho sektoru stomatologhichnoji dopomoghy Publichne administruvannja: teorija ta praktyka. 2018; 2(20): 1-13.

18. Mochalov Ju.O., Majstruk P.O., Sabov A.V., Lokota O.V. Vyznachennja peredumov dlja realizaciji reghionaljnykh proghram profilaktyky karijesu zubiv na terytoriji Zakarpatsjkoji oblasti. Rezhym dostupu https://dspace.uzhnu.edu.ua/ jspui/handle/lib/22422.

19. Khomenko L.O., Shapovalova Gh.I. Ghlyboke ftoruvannja - metod profilaktyky karijesu zubiv. Oghljad literatury Chastyna 2. Dentyn - ghermetyzujuchyj likvid. Profilaktychna ta dytjacha stomatologhija. 2013; 1: 6-7.

Дата надходження рукопису до редакції: 27.05.2020 p.

Мета досліджень: аналіз досвіду профілактики основних стоматологічних захворювань країн Свропи з схожими біогеохімічними показниками, як Закарпаття і розробка науково-обгрунтованих профілактичних заходів.

Матеріали та методи. Аналітичний аналіз основних напрямів стоматологічної первинної, вторинної і тритинної профілактики та матеріалів статистичного центру МОЗ України за 2017 і 2018 роки з використанням статистичного, соціологічного та клінічного методу проаналізовані статистичні дані щодо стоматологічного здоров'я дітей Закарпаття за 2017-2018 роки.

Результати. Профілактика стоматологічних захворювань $є$ ефективним та економічно виправданим методом розвитку стоматологічної медицини, що доведено програмами країн Європи, які можуть бути перспективним для застосування в Україні.

Високий рівень поширеності та інтенсивності карієсу в Україні, що складає 65,8-97,7\%, в порівнянні 3 країнами Євросоюзу підтверджують, що показовим є державна програма Словаччини, де за останні 20 років це й показник тримається на одному рівні, тому Україні необхідна своя державна програма та якісні комплексні регіональні програми первинної, вторинної та третинної профілактики стоматологічних захворювань.

Найбільш ефективним способом профілактики стоматологічних захворювань і підвищення стоматологічного здоров'я є гігієнічне навчання всіх верст населення, особливо дитячого, застосування комунальної програми профілактики, проведення профілактичних стоматологічних оглядів та санація і диспансеризація.

Висновки. Запровадження цільових профілактичних програм забезпечить більш ефективне збереження та зміцнення стоматологічного здоров'я.

Ключові слова: стоматологічні захворювання, профілактика, програми профілакити, досвід країн Свропи.

Цель исследований: анализ опыта профилактики основных стоматологических заболеваний стран Европы с подобными биогеохимическими показателям, как Закарпатье и разработка научно-обоснованных профилактических мероприятий.

Материалы и методы. Аналитический анализ основных направлений стоматологической первичной, вторичной и третичной профилактики и материалов статистического центра МЗ Украины по 2017 и 2018 годы с использованием 
статистического, социологического и клинического метода проанализированы статистические данные по стоматологического здоровья детей Закарпатья за 2017-2018 годы.

Результаты. Профилактика стоматологических заболеваний является эффективным и экономически оправданным методом развития стоматологической медицины, доказано программами стран Европы, которые могут быть перспективным для применения в Украине. Высокий уровень распространенности и интенсивности кариеса в Украине, что составляет 65,8-97,7\%, по сравнению со странами Евросоюза подтверждают, что показательно государственная программа Словакии, где за последние 20 лет этот показатель держится на одном уровне, поэтому Украине необходимо своя государственная программа и качественные комплексные региональные программы первичной, вторичной и третичной профилактики стоматологических заболеваний.

Наиболее эффективным способом профилактики стоматологических заболеваний и повышения стоматологического здоровья является гигиеническое обучение всех слоев населения, особенно детского, применение коммунальной программы профилактики, проведение профилактических стоматологических осмотров и санация и диспансеризация.

Выводы. Введение целевых профилактических программ обеспечит более эффективное сохранение и укрепление стоматологического здоровья.

Ключевые слова: стоматологические заболевания, профилактика, программы профилакиты, опыт стран Европы.

Purpose of research: analysis of the experience of prevention of major dental diseases in European countries with similar biogeochemical indicators, as Transcarpathia and the development of scientifically based preventive measures.

Materials and methods. Analytical analysis of the main directions of dental primary, secondary and tertiary prevention and materials of the statistical center of the Ministry of Health of Ukraine for 2017 and 2018 using the statistical, sociological and clinical method, statistical data on the dental health of children of Transcarpathia for 2017-2018 were analyzed.

Results. Prevention of dental diseases is an effective and economically viable method for the development of dental medicine, proven by programs in European countries, which can be promising for use in Ukraine. The high level of prevalence and intensity of caries in Ukraine, which is 65.8-97.7\%, in comparison with the EU countries, confirms that the state program of Slovakia is indicative, where over the past 20 years this indicator has remained at the same level. level, so Ukraine needs its own state program and high-quality comprehensive regional programs for primary, secondary and tertiary prevention of dental diseases. The most effective way to prevent dental diseases and improve dental health is hygienic education of all segments of the population, especially children, the use of a communal prevention program, preventive dental examinations and sanitation and clinical examination.

Conclusions. The introduction of targeted preventive programs ensures the preservation and provision of dental health.

Key words: dental diseases, prevention, prevention programs, experience of European countries.

Конфлікт інтересів: відсутній.

Conflicts of interest: authors have no conflicts of interest to declare.

\section{Відомості про авторів}

Пішковці Анна-Марія Михайлівна - асистент кафедри громадського здоров'я та гуманітарних дисциплін ДВНЗ «Ужгородський національний університет»; м. Ужгород, вул. Університетська 14. annamariaremez@gmail.com, ORCID ID 0000-0002-6478-1948.

Палко Аліса Іванівна - к. біол. наук, доцент кафедри соціальної медицини та гігієни ДВНЗ «Ужгородський національний університет»; м. Ужгород, пл. Народна 1.

palko.alice@gmail.com, ORCID ID 0000-0002-2233-3602.

Рогач Іван Михайлович - д. мед. наук, професор, зав. кафедри соціальної медицини та гігієни ДВНЗ «Ужгородський національний університет»; м. Ужгород, пл. Народна 1.

ORCID ID 0000-0001-6112-3934. 